\title{
A Comparative Study of Economic Policies Based on Green Energy Transformation
}

\author{
Jianfei SHEN, Jingjie $\mathrm{LI}^{1}$ and Yidan CHEN \\ School of Economics and Management, North China Electric Power University, \\ Beijing 102206, China
}

\begin{abstract}
Faced with increasingly serious climate and environmental problems, the green transformation of the energy structure is imminent. Energy development is related to a country's economic lifeline, and the level of energy green transition is a key factor in determining the degree of low-carbon economic development. As an important way to internalize the externalities of environmental behavior, the degree of perfection of economic policies has a direct impact on the energy transition process. As an important means to promote the adjustment of energy structure, economic policies can internalize the positive or negative externalities of corporate environmental behaviors, and play an unparalleled role in the process of promoting the green transformation of energy. This article takes Germany, France, Japan, and Australia as the research objects of the four countries with relatively advanced energy transition economic policy systems, and fully analyzes the above-mentioned countries' practices in fiscal and taxation policies, green finance, and market systems, and combines China's energy transition economic policies. Implementation status, and corresponding suggestions for the construction of China's energy transition policy system.
\end{abstract}

Keywords. Energy transformation; economic policy; international comparison.

\section{Introduction}

The survival and development of human beings are inseparable from the gift of nature. The importance of ecological environment and natural resources is self-evident. In recent years, in the face of resource depletion, climate change and other environmental problems, green development has gradually become the consensus of all countries in the world. The development of green economy is inseparable from the adjustment of energy structure. Energy development is related to the country's economic lifeline. The level of green energy transformation is the key factor to determine the development of lowcarbon economy. As an important means to promote the adjustment of energy structure, economic policy can internalize the positive or negative externalities of enterprises' environmental behavior, increase the use cost of heavy polluting traditional energy through multiple channels such as environmental tax, financial compensation, market mechanism and green finance, and enhance the economic attraction of clean energy. It plays an important role in promoting the green transformation of energy.

Chinese energy transformation is in a critical transition period from government subsidies to market governance. At present, there are some problems, such as the legal

${ }^{1}$ Corresponding Author, Jingjie LI, School of Economics and Management, North China Electric Power University, Beijing 102206, China; Email: 1121859355@qq.com. 
system needs to be improved, the market role is not fully played, the policy implementation is not deep, and the policy joint efforts are not fully mobilized. The "disadvantages" of subsidies, such as the expansion of the funding gap and the lack of supply and demand information, are increasingly apparent. The top-level design of market mechanism has become a key factor for the success of energy transformation. In the process of energy transformation mechanism design, "building a car behind closed doors" is not advisable. Many developed countries have outstanding performance in the third energy transformation process. There are some advanced experiences and tortuous lessons in the design of energy transformation economic policy system. We should fully absorb and learn from the experience and lessons of developed countries in the implementation of economic policies in the process of energy transformation for China to use. is a necessary means to improve the top-level system design and promote the process of energy transformation.

However, most of the existing literatures in the field of energy transformation are based on the overall measures, and lack of special, systematic, and in-depth carding of economic policies. In view of the significance of economic policies to the current energy transformation in China, the author believes that it is necessary to fully study and learn from the energy transformation economic policies of developed countries. Therefore, taking Germany, France, Japan and Australia as research samples, this paper summarizes the policy characteristics of finance, finance, taxation and market mechanism. Combined with the current situation of China's energy transition economy policy, it analyzes the existing problems in China, which are as follows: there is no systematic legal system guidance; there is no legal system guidance; there is no legal system guidance; The experience of policy and system design is insufficient, the allocation of resources is still guided by the government, and the role of the market is weak; Financial and other related supporting measures are not in place. On the basis of learning the advanced experience of foreign countries, this paper explores the improvement measures of China's energy transformation economic policies in view of the current problems, in order to contribute to the construction of China's green economy.

\section{Comparative Analysis of Energy Green Transition Economic Policies in Developed Countries}

\subsection{Germany}

As a world-class industrial power, Germany strives to provide reliable and efficient power support for its industrial development through energy transformation strategy. Throughout the history of German energy development, its energy focus has experienced the transfer of "coal $\rightarrow$ oil and gas $\rightarrow$ nuclear energy $\rightarrow$ renewable energy". As the largest coal producer and consumer in Europe, coal once occupied an important position in Germany's energy strategy. However, due to the impact of emission reduction targets and environmental pressure, Germany has planned to realize coal withdrawal around 2030; In the oil and gas stage, due to the high import dependence of traditional oil and gas energy in Germany, the volatile political situation of oil-rich countries poses a certain threat to energy security; In addition, affected by Japan's nuclear pollution accident, Germany has become the first country in the world to abandon its nuclear weapons. The end of coal, oil and gas and nuclear energy has pushed renewable energy to the center of the German energy stage. In the process of energy green transformation, financial 
subsidies, green finance, bidding system, environmental tax and other economic policies have played an important role in promoting the development of renewable energy $[1,2]$.

The promotion of renewable energy in Germany has achieved remarkable results in the field of electric power. According to the revised renewable energy law in 2009, the proportion of renewable energy in electric power consumption should reach $30 \%$ by 2020 , but in 2015, the completion rate of this goal in Germany has exceeded 60\% [2]. In the early days, Germany adopted the fixed price mechanism of renewable energy. According to the law, power grid enterprises must give priority to the purchase of renewable energy power at a higher fixed price, and the losses are compensated by charging surcharges to power users. Although the mandatory provisions of the law ensure the priority of renewable energy and full access to the grid, with the expansion of renewable energy power generation scale, the rising electricity price cost makes it difficult for power consumers to bear. In order to further optimize the resource allocation of renewable energy power in the supply and demand market, Germany introduced the market mechanism of premium subsidy in 2014. In 2017, the method of determining the amount of subsidy was fully transformed into bidding, and the excess profits in the field of green power were controlled by market forces, to support the domestic green transformation, At the same time, promote the construction of European clean energy power market. In addition to the renewable energy pricing mechanism, green power products are also a highlight of the green transformation of German power. Germany's highly open electricity market gives both sides full freedom of choice, which urges power companies to actively develop green power products to cope with market competition. The prosperity of green power products accelerates the pace of energy transformation in Germany to a great extent. In addition, Germany is one of the few countries in the world to fully implement the carbon emission trading system. The additional carbon emission price reduces the profit margin of coal power generation, and the competitiveness of renewable energy power generation continues to improve [3-6].

In the process of energy green transformation, Germany has also designed a wide range of incentive and disciplinary mechanisms to improve the attractiveness of clean energy and energy conservation and emission reduction through economic means, and reduce the economy of traditional energy by means of ecological tax, to help achieve the strategic goal of green transformation. In terms of incentive mechanism, the government has set up an energy efficiency fund for energy conservation publicity and renovation. At the same time, the proportion of renewable energy in the heating system is increased by providing soft loans and investment subsidies. The German bank of credit for reconstruction also provides financial support for building energy conservation renovation in the form of long-term low interest loans. In addition, in order to improve the research and development of green energy technology, the German government has launched seven "energy research projects" and invested billions of euros in this regard, hoping to provide intellectual support for green transformation through technological innovation. In terms of punishment mechanism, the most obvious performance is the differential collection of ecological tax. The German government exempts clean energy from ecological tax, but increases the amount of fossil energy tax several times in the relevant bills of ecological tax reform. Part of this tax is used to support the development of renewable energy, and the rest is returned to the public through social security. Germany's regulations on energy-saving tasks of enterprises also contain certain punishment mechanism. The government requires energy supply companies to achieve a certain proportion of energy-saving goals every year. At the same time, large 
enterprises need to conduct energy audit every four years. Enterprises that fail to complete the task will face hundreds of millions of euros of punishment $[5,7,8]$.

\subsection{France}

In the last century, the focus of energy in France has been oil for a long time, but the two oil crises have brought a fatal impact on the French economy. Since the 1970s, the government has tried to shift the direction of energy to nuclear power and develop it as the national basic energy. At present, France has become the country with the highest utilization rate of nuclear energy in the world, and the proportion of domestic nuclear power generation has been maintained at more than $70 \%$ for a long time. Unlike Germany, which pursues the principle of reducing nuclear power, France has always been difficult to reduce the proportion of nuclear power due to the restrictions of economic environment, industrial development, and energy status. Specifically, in recent years, the economic environment of France has been depressed, and the low price of nuclear power generation has strongly supported the development of French economy; In industry, the nuclear energy industry is an important foundation of French industry. Once the nuclear policy changes, it is bound to hit the French nuclear industry and affect the "industrial Renaissance" plan; In addition, due to the shortage of primary energy in France, the severe pressure of environmental protection limits the import and use of traditional energy. As a clean energy with low carbon and environmental protection, nuclear energy is an important guarantee for France to achieve energy independence. However, after the Fukushima nuclear power plant accident in Japan, France has realized that the transformation to renewable energy is the main theme of the current energy market. The government has repeatedly put forward the development goals of reducing the dependence on nuclear power and improving the utilization rate of renewable energy. It can be predicted that the future energy development of France should be a situation where clean energy and renewable energy can go hand in hand [9].

In order to realize the diversification of energy supply, France issued the green development energy transition law in 2015, which contains some economic measures to promote energy development. In terms of power generation, the government plans to improve the competitiveness of renewable energy power generation through premium subsidies; In terms of tax policy, the bill mentions that the amount of carbon tax should be doubled before 2030, and the return proportion of energy-saving transformation projects in tax credit should be increased; In terms of finance, we will relax the restrictions on the number of interest free ecological loans, increase the original number of 30000 to 100000 per year, and promote the issuance of green bonds; In terms of financial support, the special fund is set up to provide financial support for energy transformation projects. In addition, the "energy check" project is specially set up for poor families, from which people with family difficulties can get a certain amount of energy consumption subsidies. However, the project specifically excludes heavy oil consumption, which has serious pollution hazards; In terms of ecological investment, the Ministry of ecology plans to invest 10 billion euros in three years as a guarantee for the implementation of the energy plan. In order to achieve the emission reduction targets mentioned in the bill, the French government introduced a carbon budget system in the same year, setting carbon emission caps for different industries in a five-year cycle [1013].

According to the World Bank, environmental tax is the main tool to realize green growth. The reform of ecological tax in France has also played an important role in 
energy transformation. Since 1999, the country has implemented the "general tax on pollution activities" (TGAP), which integrates and simplifies the original environmental tax and cancels the environmental tax and fee originally managed by the environment and energy control agency, which is related to atmosphere, noise, crude oil, air pollution and so on and TGAP, a new tax, will be brought under the jurisdiction of the French Customs General Administration. In 2001, the energy tax was officially implemented in France. According to the policy, only the enterprises whose annual energy consumption exceeds a certain limit will be taxed, while the tax-free strategy will be implemented for households, agriculture, forestry, fishery, and transportation. The qualified enterprises can also enjoy the benefits of using this part of the tax to offset the labor tax. In order to promote the development of biofuels, since 2005, the government has set a minimum annual sales quota for producers and sellers of biofuels in the industry. Enterprises that fail to meet the target need to pay general tax on pollution activities. France's environmental protection tax is highly earmarked, most of which are used for environmental pollution and control projects, which is also an important reason for the success of its environmental tax reform. However, the road of environmental tax reform in France is not plain sailing. The famous "yellow vest" Movement broke out in France in 2018. The reason is that the government's carbon tax on diesel and gasoline has aroused strong public resistance, and the fuel tax increase plan planned to be implemented in 2019 has been defeated [14-17].

\subsection{Japan}

Due to the objective limitations of land area and geographical environment, Japan's energy self-sufficiency rate has been low for a long time. Although the development of nuclear power has improved Japan's energy independence to a certain extent since the 1970s, the sudden Fukushima incident directly led to the collapse of Japan's nuclear power blueprint. Since then, the government has intensified the promotion of renewable energy, In the fifth energy basic plan issued in 2018, renewable energy was officially established as the "main energy" of the country. On the basis of controlling primary energy carbon emissions, Japan's development of green energy is mainly to improve energy efficiency through energy management mechanisms such as environmental accounting, while strengthening the promotion of new green energy such as hydrogen energy and solar energy, and promoting the realization of energy strategy through the dual way of "saving and open source" [18].

In terms of controlling primary energy carbon emissions, Japan's economic measures mainly include building a carbon trading market and levying a carbon emission tax. Japan's carbon trading market sprouted in the "Kyoto Protocol" in 1997. At that time, the government did not put forward rigid requirements for enterprises' emission reduction targets, and the relevant enterprises made emission reduction commitments voluntarily according to their own conditions. With the gradual development of carbon trading system, the current carbon trading system in Japan has two management levels: the central government and the local government. The central government's carbon market implements voluntary trading rules, while the local government adopts mandatory rules. In addition, Japan began to levy carbon tax on fossil fuels in 2007. Similar to France and Germany, Japan's carbon tax revenue is also used for environmental protection. However, different from France, Japan does not distinguish between enterprise users and resident users when imposing carbon tax, and both have the same obligation to pay carbon tax $[19,20]$. 
Under the guidance of the concept of circular economy development, Japan began to build its own environmental legal system from the 1990s, and derived the advanced environmental accounting system Japan's environmental basic law clearly regards enterprises as the subject of responsibility for environmental issues, and puts environmental issues such as resource recycling and energy conservation and emission reduction under the jurisdiction of enterprise environmental accounting, which further improves the relationship between national energy strategy and enterprise environmental objectives. The documents regulating the disclosure of enterprise environmental accounting information in Japan mainly include guidelines for environmental report and guidelines for environmental accounting. These guidelines encourage enterprises to voluntarily disclose environmental accounting information, and provide detailed guidance on how to measure environmental elements and how to write environmental report. In addition, the Japanese government and relevant media also have a lot of activities to award the environmental information disclosure of enterprises. The Ministry of environment has set up the "Enterprise Environmental Report Award", and the Toyo economic news has also set up the "Environmental Report Award", which is conducive to encouraging enterprises to make efforts to improve their environmental reputation and further form a good environmental protection atmosphere in the society. Under the good institutional environment and incentive measures, although there is no official mandatory requirement for enterprises to disclose environmental accounting information, it is the mainstream practice for Japanese enterprises to prepare environmental reports separately. The complete disclosure of environmental information helps to build a green and transparent environmental protection system, the careful accounting of environmental costs helps to improve the energy management level of enterprises, and the sound development of environmental accounting plays a good auxiliary role in Japan's energy transformation [21, 22].

In the promotion of green energy, the implementation of green finance and strengthening financial subsidies are the main economic practices adopted by the Japanese government. Japan's green financial system is excellent. At the policy level, the Ministry of environment specially compiled "environment and Finance: the new role of financial sector in building a low-carbon society" in 2010 to coordinate the relationship between financial sector and environmental sector, and issued "principles of financial action in the 21 st century" the next year to strengthen the role of financial instruments in promoting environmental protection; At the implementation level, Japanese financial institutions offer low interest loans to environmental protection R \& $\mathrm{D}$ activities, environmental protection projects and enterprises that meet the environmental protection standards. Meanwhile, the Ministry of environment and the environmental association have set up green funds to provide environmental protection financial support for enterprises. The government will also provide guarantees for certain environmental protection projects to reduce enterprise risk. In addition, the government and financial institutions spare no effort in the issuance and promotion of green bonds. In the promotion of hydrogen energy, solar energy and other new energy, Japan mainly adopts the method of strengthening financial subsidies. In the aspect of hydrogen energy development, the government has set up subsidies for clean energy vehicles and related hydrogenation stations, and owners of hydrogen powered vehicles can also enjoy tax reduction. In addition, the Ministry of economy, industry and trade and the Ministry of environment also provide large amount of financial support for hydrogen energy research and development every years; As for the promotion of solar energy, Japan began to 
implement the "sunshine plan" in the 1970s, which subsidized households who installed solar power generation systems, covering nearly half of the installation costs [23-26].

\subsection{Australia}

Australian energy structure has been dominated by coal and natural gas for a long time, which is different from the situation that the above-mentioned countries are facing the shortage of resources to varying degrees. Australian primary energy reserves are very abundant. However, although favorable natural conditions provide reliable guarantee for energy security, it is also difficult for the country to get rid of its dependence on traditional energy in the short term. As the first country in the world to set renewable energy targets, Australia has long recognized the importance of energy transformation and climate protection. Frequent mountain fires and other natural disasters have also attracted much attention to its environmental protection. In terms of economic policy, Australia has some advanced experience in green finance and green certificate trading. According to the latest report of Ernst \& young, Australian renewable energy investment attraction has risen to the third place in the world. However, in view of the high politicization of the country's energy transformation issue. The game between parties has also brought some resistance to the implementation of Australian energy economic policy [27].

Australia is one of the main markets of global green finance. As a professional green financial investment institution, clean energy finance company has invested a lot of money in renewable energy since its establishment. In addition to focusing on potential energy transformation projects, under the pressure of performance evaluation, the agency also pays attention to mining private capital and controlling project risks. In terms of green financial products, CBI data show that as of the first half of 2019, Australia has issued more than 15 billion green bonds, ranking third in the Asia Pacific region. The country's green bonds are mainly invested in low-carbon buildings, in addition to renewable energy, green transportation and solid waste management. In addition to green bonds, Australia also implements the green electricity certificate trading system nationwide, and divides it into two categories according to the size of electricity. The first category is for large-scale power generation equipment, and the second category is for small-scale power generation facilities such as roof solar energy. High energy consumers need to purchase a certain amount of green electricity certificate quota to achieve the renewable energy goal [28-30].

Although some advanced experience has been gained in policy design, the game of interests between political parties has brought great uncertainty to Australian green transformation road. The carbon tax system, which was launched in 2011, was soon abolished after the new government took office. The energy security plan, which was highly praised by the former prime minister, was also abolished in 2018 . Energy policy has become a political tool between parties. Although the current government has launched a new "climate solution" as an alternative to the "energy security plan" and proposed measures such as setting up emission reduction funds, the new government is not very active in the development of renewable energy. It has stopped the research funding for energy transformation projects, developed new coal mining projects, and put forward some suggestion. A series of negative behaviors, such as the construction of coal-fired power plants, make the country's energy transformation road full of fog [31]. 


\section{The Implementation Status of China's Energy Green Transformation Economic Policy}

As a big energy consuming country, China has long maintained a coal-based energy consumption structure, which is different from the typical energy transformation process of "wood $\rightarrow$ coal $\rightarrow$ oil and gas $\rightarrow$ renewable energy" in developed countries. In the third wave of energy transformation, China is likely to leap directly from coal to renewable energy, which poses a great challenge to the top-level system design. Although Chinese energy green transformation process is arduous and started late, and is still in the exploration period of energy transformation policy design, as a responsible country that abides by its promise, Chinese energy transformation is unstoppable under the commitments of international climate treaties such as the Paris Agreement. In recent years, in order to promote the green transformation of energy, China has made some progress in the design of economic policies. This paper mainly discusses from the fiscal and tax policies, green finance, and market mechanism. It is worth noting that in recent years, the policy trend has gradually changed from government subsidies to market governance, which is an important step from the exploration period of energy transformation to the mature period in China.

In terms of fiscal policy, the renewable energy law issued in 2006 stipulates that special fund should be set up for the development of renewable energy. Under the guidance of the law and policy, China has provided certain financial support for renewable energy power generation, new energy vehicles, green technology research and development and other fields. Electric power is the main channel of renewable energy utilization. Since the implementation of the fixed price subsidy policy in 2006, Chinese renewable energy installed capacity has steadily increased, and now ranks first in the world. The subsidy fund of renewable energy power generation in China mainly comes from the surcharge imposed on power consumers, which has been adjusted six times from 2006 to 2015 to make up for the expanding subsidy fund gap. In addition, in order to reduce the consumption of fossil fuels, the government has set up special funds to subsidize the purchase of new energy vehicles, and consumers can also be exempted from purchase tax when they buy new energy vehicles. In terms of R \& D of renewable energy technology, by the end of 2019, the central government has invested more than 3 billion yuan in the development of green energy technology, which has greatly improved the utilization level of renewable energy such as solar energy, wind energy and biomass energy. The construction of smart energy system is also an important part of technology research and development. Big data, blockchain and other intelligent technologies have played a great role in improving the proportion of green energy consumption [32].

In terms of tax policy, China has not yet issued a separate energy tax or carbon tax collection regulations, but has stipulated some tax items in the existing taxes, such as resource tax, consumption tax and value-added tax, to promote the adjustment of energy structure, which is embodied in the increase of taxes on the production and marketing chain of primary energy, and the setting of preferential terms to reduce the tax burden of green energy. In terms of increasing the tax burden of primary energy, the legislation of resource tax has been completed. Energy minerals are the important tax objects, and the exploitation of crude oil, coal, and natural gas all need to pay a certain amount of resource tax; When consumers buy gasoline, diesel, and other refined oil, they need to pay consumption tax in accordance with specific quota; In addition, the environmental protection tax law was officially promulgated in 2018. The tax on air pollution, solid waste, water pollution and other pollutants can also increase the use cost of coal and 
other traditional energy to a certain extent, and improve the economic attractiveness of renewable energy. In terms of reducing the tax burden of green energy, wind power generation and hydropower generation can enjoy certain value-added tax preferences, imported renewable energy equipment can be exempted from tariff and import valueadded tax, and there are special provisions for renewable energy utilization enterprises in the preferential terms of income tax.

In terms of green finance, although China started late, it has made many beneficial attempts in green credit and green bonds. As early as 2006, the renewable energy law stipulated that qualified renewable energy projects could enjoy the financial discount when making financial loans. Subsequently, relevant departments successively issued the green credit guidelines, the green financial bond announcement, the guiding opinions on the construction of a green financial system, and the green financial bond announcement Guidance documents such as "guidance on supporting the development of green bonds" are used to strengthen the role of financial instruments in promoting green transformation. Relevant data show that by the end of 2019, Chinese green bond issuance scale has reached trillions, and the balance of green credit of major financial institutions has reached trillions, ranking among the top in the world. In addition, other green financial products have also been developed, covering insurance, trust, leasing and other financial fields. At the same time, China has set up several green finance reform and innovation pilot zones in recent years, and has carried out beneficial practice in the construction of green credit platform, green bond discount, green project library and other aspects [33, 34].

In terms of market mechanism, Chinese market trading mechanism in terms of carbon emission rights and green power certificates is in its infancy. However, with the growing drawbacks of financial subsidies, relying on the market as an "invisible hand" to optimize resource allocation is the only way for Chinese energy transformation. Chinese carbon emission trading market construction level is relatively good, and its pilot started in 2013. In order to promote the orderly construction of carbon emission trading market, the national development and Reform Commission issued the "national carbon emission trading market construction plan" in 2017, and the Ministry of ecological environment also published the draft of "Interim Regulations on the management of carbon emission trading" in 2019 to improve the specific trading rules. At present, the allocation of carbon emission rights is different in different regions, but most of the quota allocation is free, and the paid allocation is less. Besides carbon emission rights, the emergence of green power certificate trading also helps to improve the cost performance of renewable energy. Under the background of the gradual decline of financial subsidies, the government began to implement green certificate trading in 2017. Qualified renewable energy power generation enterprises can apply for green certificate, and the trading income of green certificate can replace the government subsidies to a certain extent.

\section{The Enlightenment of International Experience on Chinese Energy Green Transformation Development}

\subsection{Strengthen The Construction of Legal System and Improve the Guarantee System of Transformation}

To a certain extent, the top-level design of the system determines the keynote of a country's energy transformation. The implementation of economic policies for energy 
transformation depends on the protection of legal system. The system of keeping pace with the times is closely related to the development of green energy. Throughout Germany, Japan and other developed countries, all of them accelerate the process of green energy transformation through the gradual improvement of the legal system. German "renewable energy law" has undergone several revisions. French energy transformation also focuses on the "green development energy transition law". Japan has promulgated more than 700 laws and regulations to regulate the construction of circular economy system. Although China has promulgated a number of laws related to energy transformation, there is a lack of basic laws to lead the energy transformation. The promotion of energy transformation is not enough. Moreover, the formulation of energy transition economy policy involves many government departments, and the inconsistency of detailed rules among various departments also increases the difficulty of the implementation of relevant policies. Therefore, China should further improve the system design of energy transformation, promote the implementation of energy law as soon as possible, and strengthen coordination and communication between government departments to avoid the phenomenon of going their own way [21, 35].

\subsection{Innovating the Way of Policy Implementation to Promote Energy Transformation Efficiently}

Legislation is the basis and foundation of the work, but the efficient operation of the policy system requires the corresponding implementation mechanism. Therefore, the relevant government departments should not only improve the law, but also design the supporting implementation work, so that the policy can be implemented more efficiently. In the process of the implementation of Chinese energy transformation policy, the incentive mechanism is a very important aspect that China does not pay enough attention to. Japan has set up a wealth of commendation and reward methods to encourage enterprises to actively disclose environmental information, creating a good institutional environment for the development of its environmental accounting. The brand effect of an enterprise is an intangible asset, and China can also reward the enterprises that actively respond to government policies. In order to pursue the brand effect and cooperate with the implementation of government policies, enterprises can promote the understanding and attention of the whole society to the energy transformation, and promote the formation of a healthier and reasonable market atmosphere and market rules.

\subsection{Pay Attention to the Market Governance Mechanism and Optimize the Allocation of Transformation Resources}

In the early stage of renewable energy development, government subsidies are commonly used to improve the utilization rate of renewable energy. However, this method is not suitable for long-term use. On the one hand, it will bring heavy financial burden to the government; on the other hand, it may lead to blind expansion of renewable energy. At present, Chinese renewable energy tariff subsidies have been delayed in fund payment and the subsidy gap has expanded, and the rate of wind and light abandonment has been maintained at a high level. At present, the government has begun to try to transition from the subsidy promotion period to the market regulation period, and has carried out beneficial exploration in the power market reform, green power certificate trading and other market-oriented mechanisms. However, overall, the government is still in the dominant position, and the market plays an insufficient role in regulating the 
energy transformation. Therefore, on the basis of fully learning from the experience of developed countries, China should actively introduce the market-oriented mechanism while accelerating the decline of subsidies, refer to the mode of Japanese carbon trading system, further improve the domestic carbon emission trading market, reduce the proportion of primary energy through market trading, and give full play to the role of market governance in the process of energy transformation, To adjust the contradiction between supply and demand, optimize the allocation of energy resources.

\subsection{Improve the Effect of Policy Mix and Make Steady Progress According to Local Conditions}

From the experience of energy transformation in developing countries, an economic policy has never appeared alone. It is a common practice to combine financial, tax, financial and other economic measures to promote energy transformation. Different economic policies have different emphases. Tax policies can adjust the use costs of different types of energy according to the positive and negative environmental benefits. Fiscal policies are biased towards government financial support. Financial policies can fully mobilize the enthusiasm of green investment of social capital. Market mechanisms focus on the optimal allocation of resources, Environmental accounting can calculate the "environmental account" and "economic account" of energy transformation. Generally speaking, Chinese energy transition economic policy is biased towards financial support. We should learn from the energy tax reform process of other countries to improve the tax policy, and the environmental accounting system needs to be further developed. In addition, studies have shown that the efficiency of energy transformation is closely related to economic development, population growth and other regional conditions. China has a vast territory, and the energy situation and transformation pace may vary greatly in different regions. In the specific implementation process of economic policies, we should adjust the combination types of economic policies according to local conditions. On the basis of adhering to the party's overall leadership, we should give full play to the policy forces to promote the process of energy transformation in line with the regional development rules and reduce the people's living burden.

\section{Conclusion}

This article takes Germany, France, Japan, and Australia as the research objects of the four countries with relatively advanced energy transition economic policy systems, and fully analyzes the above-mentioned countries' practices in fiscal and taxation policies, green finance, and market systems, and combines China's energy transition economic policies. Implementation status, and corresponding suggestions for the construction of China's energy transition policy system. On the basis of learning foreign advanced experience, this article explores the improvement measures of China's energy transition economic policy in view of current problems, with a view to contributing to China's green economy construction. 


\section{Acknowledgement}

[Fund project] general project of National Social Science Foundation of China "Research on economic policy system for promoting green transformation of energy industry" (19bg1011), initiated by Shen Jianfei.

\section{References}

[1] Zhang N, Xue M M, Wu X Y, Dai H C, Zhang Y Z and Liu Z D 2020 Comparison and enlightenment of energy transformation at home and abroad China Electric Power 1-8.

[2] Lin L, Wu Y N, Dong Z F and Geng H Q 2017 Policy innovation of energy transformation in Germany and the United States and its enlightenment to China Environmental Protection 45 (19) 64-70.

[3] Xu T 2014 Progress, challenges, and prospects of energy transformation in Germany Macroeconomic Management (03) 85-87.

[4] Li X 2020 China, one belt, one road in the US, Japan and India: A comparison of clean energy diplomacy: implications for China's green "one belt and one way" construction China Soft Science 2020 (07) 1-15.

[5] Jin L 2016 Goal and path of energy structure transformation: Comparison and Enlightenment between the United States and Germany Exploration of Economic Issues (02) 166-172.

[6] Sun Q, Zhang T and Li J 2016 The development of Korea's carbon emissions trading system and its enlightenment to China Journal of Wuhan University (Philosophy and Social Sciences) 69 (02) 73-78.

[7] Liu P 2010 Review of eco tax reform in OECD countries Chongqing Social Sciences (03) 62-69.

[8] Xiu Q, Zhang Y and Yin Y 2019 Development experience and enlightenment of energy saving service industry in the United States, Japan and Germany China Energy 41 (03) 18-21.

[9] Yao S and Zhang S 2019 Research on the dynamic relationship between renewable energy consumption, carbon emissions and economic growth Journal of Humanities (05) 42-53.

[10] Hao X, Luo Y, Lin J and Cao D 2017 Sewage potential development depends on timely subsidy policy China Water Supply and Drainage 33 (12) 12-18+23.

[11] Wang Y 2015 New measures of energy transformation in France: on the draft of energy transition law for green development Global Outlook on Science, Technology and Economy 30 (06) 5-6+15.

[12] Tian D and Xu H 2018 The legal guarantee of green growth and energy transformation in France China Energy 40 (01) 32-35.

[13] Chen X and Chen Y 2018 The role of carbon budget in Global Climate Governance from the perspective of science and policy Climate Change Research Progress 14 (06) 632-639.

[14] Cigu E, Petrior M B, Nu A C, et al. 2020 The nexus between financial regulation and green sustainable economy Sustainability 12.

[15] An S 2015 Comparison and experience of ecological tax system construction of virtue law Administrative Reform (02) 65-69.

[16] Tian D, Zhang H and Gao H 2009 Analysis of foreign policies and measures for promoting the application of automotive biofuels Bus Technology and Research 32 (02) 58-61.

[17] Ye L 2019 On the construction of environmental tax revenue use system in China Journal of Shanghai University of Finance and Economics 21 (01) 139-152.

[18] Gao H, Yang Y, Liu Y, Liu J, Liu Y and Wu M 2020 World energy transformation trend and transformation practice of major countries Petroleum Science and Technology Forum 39 (03) 75-87.

[19] Wang T, Zhang Z and Sun X 2020 The development of carbon market under the background of low carbon and its enlightenment to petroleum and petrochemical industry Liaoning Chemical Industry 49 (06) 647-650.

[20] Hao S 2013 Analysis on the implementation of carbon emission reduction policy tools in major developed countries Renewable Resources and Circular Economy 6 (11) 10-12.

[21] Fu Y 2019 Comparison and reference of environmental accounting information disclosure between Chinese and Japanese enterprises Financial and Accounting Bulletin (22) 123-126.

[22] Osamu O 2006 Environmental accounting in Japan World Forestry Research (04) 76-80.

[23] Liu B 2016 Practice and enlightenment of green finance in Japan Hebei Finance (10) 28-32. 
[24] Li W, Zhang Y, Zhang N and Li S 2020 Pollution prevention and environmental protection industry development in the process of industrialization in Japan: Perspective of financial support Heilongjiang Finance (06) 51-55.

[25] You S, Zhang Z, Zhou Y, Du G, Wan H, Xu P and Bao L 2019 Industrial policy and Enlightenment of hydrogen pioneer countries Petroleum Science and Technology Forum 38 (05) 57-66.

[26] Gao L 2014 The development experience of Japan's solar energy industry and its enlightenment to China Journal of Hebei Institute of Software Technology 16 (01) 13-16 + 26.

[27] Li H 2011 New energy development in Australia: Law, policy, and enlightenment Theory Monthly (12) 147-149.

[28] $\mathrm{Su} \mathrm{B}$ and Qu K 2016 International experience and Enlightenment of green finance development International Finance (05) 75-80.

[29] Wu G 2017 International experience of green finance performance evaluation North China Finance (07) 77-80.

[30] Xu J and Liu M 2020 Experience and enlightenment of promoting green development in Australia Zhejiang Economy (03) 75-77.

[31] Hou G 2020 Adjustment of Australian climate policy and its impact 2020 Regional and Global Development 4 (05) 116-133 + 159.

[32] Niu Z, Guo C, Tang W, Li L, Cai Z and Han Y 2019 The technical characteristics and development path of "Internet plus intelligent energy" Power Big Data 22 (05) 6-10.

[33] Yang P 2020 China green finance development prospects China Finance (14) 42-43.

[34] Xu X and Qin Y 2020 Practical experience and improvement path of green finance development in China People Forum (30) 72-73.

[35] Qiu Z and Liu Y 2020 Promoting ecological civilization construction with green finance Theoretical Exploration (06) 83-89. 